\title{
Biomass for Residential and Commercial Heating in a Remote Canadian Aboriginal Community
}

\author{
James D. Stephen ${ }^{\mathrm{a},{ }^{*}}$, Warren E. Mabee ${ }^{\mathrm{a}}$, Amadeus Pribowo ${ }^{\mathrm{b}}$, Sean Pledger ${ }^{\mathrm{c}}$, Randy Hart ${ }^{\mathrm{d}}$, Sheldon Tallio ${ }^{\mathrm{d}}$, \\ and Gary Q. Bullc

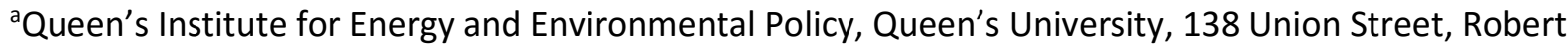 \\ Sutherland Hall, Kingston, Ontario, Canada K7L 3N6 \\ ${ }^{b}$ Indonesia International Institute for Life Sciences, Jl. Pulomas Barat Kav 88, Jakarta Timur 13210, \\ Indonesia \\ 'Department of Forest Resources Management, University of British Columbia, 2424 Main Mall, \\ Vancouver, British Columbia, Canada V6T $1 Z 4$ \\ ${ }^{\mathrm{d} N u x a l k}$ Development Corporation, PO Box 852, Bella Coola, British Columbia, Canada VOT 1C0 \\ *Corresponding Author: jstephen@tlbio.com
}

\begin{abstract}
Most residents of Canada's 300 remote communities do not have access to natural gas and must rely upon higher cost and/or less convenient heat sources such as electric heat, heating (furnace) oil, propane, and/or cord wood. This research sought to determine the techno-economic feasibility of increasing biomass utilization for space and hot water heating in remote, off-grid communities in Canada and abroad using a two-option case study approach: 1) a district energy system (DES) connected to a centralized heat generation energy centre fuelled by wood chips; and 2) a decentralized heating option with wood pellet boilers in each individual residence and commercial building. The Nuxalk First Nation Bella Coola community was selected as a case study, with GIS, ground surveys, and climate data used to design DES routes and determine heat demand. It was determined that biomass has the potential to reduce heat costs, reduce the cost of electricity subsidization for electrical utilities, reduce greenhouse gas emissions, and increase energy independence of remote communities. Although results of the analysis are site-specific, the research methodology and general findings on heat-source economic competitiveness could be utilized to support increased bioheat production in remote, off-grid communities for improved socio-economic and environmental outcomes.
\end{abstract}

\section{Keywords}

Biomass, bioheat, district energy, district heating, remote community, aboriginal

\author{
Abbreviations \\ bdt - bone dry tonne \\ DES - District Energy System \\ DN - Diamètre Nominal/Nominal Diameter \\ GIS - Geographic Information System \\ GPM - Gallons per minute \\ kWh - kilowatt hour \\ MWh - Megawatt hour
}

\section{Introduction}

\subsection{Biomass Heat}

The low cost of natural gas, made possible by advances in extraction technologies to increase supply combined with a relatively flat demand curve over the past five years, has greatly reduced the space, 
hot water, and process heating costs of households and businesses across Canada [1]. However, natural gas is used by only $47 \%$ of households in Canada for space heating. Most of the remaining $53 \%$ of homes must rely upon higher cost and/or more inconvenient electric heat (e.g., baseboard for space heating; electric hot water heaters) (37\%), heating (furnace) oil (9\%), propane (1\%), and/or biomass (6\%) as their primary source of heat [2]. While a large percentage of the biomass used for space heating in Canada is in the form of cord wood (firewood), wood pellets are becoming a more mainstream option for consideration in fuel selection. Like heating oil or propane, wood pellets - which are produced from compressed sawdust - can be continuously fed to a boiler or furnace without the need for daily manual reloading. This is a significant advantage over cord wood in terms of ease of use and convenience [3].

Another highly convenient heating option that enables significant economies-of-scale in heat supply and has been widely deployed in European cities and towns is district heating. District heating systems, or district energy systems (DES), consist of one or more centralized heat generation facilities and a network of pipes to deliver hot water or steam to two or more separate buildings. Instead of each building having its own furnace, boiler, stove, or electric heaters, a heat exchange system connects the home heating system with the hot water/steam pipes of the district heating system. In Canada, the first DES was introduced in London, Ontario in 1879 and there are currently approximately 130 systems operating across the country [4]. Many are either found in large urban centres, university campuses, or hospital complexes, but there are also examples of DES' providing heat for smaller communities such as OujéBougoumou, Québec; Drake Landing, Alberta; and Revelstoke, British Columbia (BC) [4][5]. District heating energy centres can be fueled by all the same fuels that can be used at the individual residence level, including natural gas, heating oil, propane, and biomass. However, the larger scale of centralized energy centres, as compared to distributes furnaces/boilers, also enables the use of lower grade biomass types, such as wood chips and hog fuel (residues containing bark), that are typically unacceptable for residential consumption.

\subsection{Purpose and Case Study}

The purpose of this research was to determine whether increased biomass utilization in Canada's remote communities could reduce the delivered cost of space and hot water heat for residents and commercial businesses. The Nuxalk (pronounced Noo-halk) First Nation (aboriginal peoples) community living on the Bella Coola Reserve was selected for a community case study that could be used to inform a broader assessment of bioheat and bioelectricity consumption in Canada's 300 remote, off-grid communities. Many of these communities have commonalities with Bella Coola, including heating fuel options and pricing and access to abundant biomass feedstocks. The Bella Coola Valley is a remote area on the west coast of BC, approximately $450 \mathrm{~km}$ north of Vancouver. The Valley, with a total population of approximately 1900, contains several communities, including the unincorporated village of Bella Coola, the Bella Coola subdivision of Four Mile, Hagensborg, and the hamlets of Saloompt, Nusatsum, Firvale, and Stuie. The Bella Coola First Nations Reserve covers half of Bella Coola village and all of Four Mile. Approximately 850 people live on the Bella Coola Reserve. The Bella Coola Valley is accessible by boat, air, or road via Highway 20 (Chilcotin-Bella Coola) from Williams Lake. However, Bella Coola is not connected to either the natural gas grid or the main $\mathrm{BC}$ electrical grid.

Like residents of many of the communities not connected to the natural gas grid in Canada, residents of Bella Coola face high costs for space heating - particularly when cord wood is unacceptable due to inconvenience or the inability of the homeowner to handle large logs (e.g., elderly). Most homes in the community have a combination of heating strategies for space heating and hot water. Most hot water is heated electrically, which is normally a high-cost option but is particularly high in Bella Coola because the community relies upon diesel generation for a significant portion of its electricity supply (a run-of- 
river hydro project also generates electricity for the microgrid). This is also a very energy inefficient means of hot water heating. Space heating for residences is typically a combination of cord wood stove and backup heating oil, propane, or electricity. Both propane and heating oil need to be transported significant distances by road to Bella Coola and are subject to large commodity price swings. Electric space heating in Bella Coola is high cost for both consumers and BC Hydro, the electricity generator which charges less than half the cost of generation to Bella Coola consumers. The rates are subsidized by other BC Hydro customers. Estimates on yearly energy consumption for heating oil, propane, and diesel are provided in Table 1. Columbia Fuels, the primary heating oil supplier in Bella Coola, estimates that, on average, $1700 \mathrm{~L}$ of heating oil are used by each oil-consuming Reserve residence per year, for a total of 344,000 L for all residences [6]. Commercial buildings use either propane or heating oil. Cord wood consumption, given the unregulated market and variety of cord wood sources, has not been quantified officially but is considered to have a major share of the heating market.

The Bella Coola Valley is also an economically challenged area, with average income on the reserve less than $40 \%$ of the British Columbia average (most recent statistics from 2000 Census [7]). The combination of low income and high energy costs encourages families to seek income assistance and energy subsidization. This creates a situation of government dependency and provides a disincentive to seek employment since employed persons (including even those working for minimum wage) do not qualify for the higher energy subsidies. The use of biomass for space and hot water heating is one potential option to lower energy costs and reduce reliance on energy subsidization. At the same time, utilization of local forest resources for energy production could create local jobs and keep the money spent on heating in the community rather than benefiting importers of heating oil and propane.

Table 1. Yearly Consumption of Selected Energy Types for Reserve Buildings

\begin{tabular}{|c|c|c|c|}
\hline Sector & Heating Oil & Propane & Electricity \\
\hline Residential & $344,000 \mathrm{~L}$ & $88,000 \mathrm{~L}$ & $2,766,000 \mathrm{kWh}$ \\
\hline Non-Residential & $91,000 \mathrm{~L}$ & $22,000 \mathrm{~L}$ & $1,718,000 \mathrm{kWh}$ \\
\hline Total & $435,000 \mathrm{~L}$ & $110,000 \mathrm{~L}$ & $4,484,000 \mathrm{kWh}$ \\
\hline Conversion Efficiency & $80 \%$ & $90 \%$ & $100 \%$ \\
\hline Estimated Cost & $\$ 1.40 / \mathrm{L}$ & $\$ 0.90 / L$ & $\$ 0.13 / k W h\left(\$ 0.41 / k^{2} W^{*}\right)$ \\
\hline Energy Content & $38.7 \mathrm{MJ} / \mathrm{L}$ & $25.6 \mathrm{MJ} / \mathrm{L}$ & - \\
\hline Cost of Heat & $\$ 163 / \mathrm{MWh}$ & $\$ 141 / \mathrm{MWh}$ & $\$ 130 / \mathrm{MWh}\left(\$ 410 / \mathrm{MWh}^{*}\right)$ \\
\hline
\end{tabular}

*Estimated cost of generation for BC Hydro based upon diesel efficiency of 34\%, diesel cost of $\$ 1.15 / \mathrm{L}$, and O\&M costs (including labour) of $\$ 300,000 / y r$. Retail price is approximately $1 / 3$ the cost of generation.

Source: [6]

\section{Materials and Methods}

The research methods utilized for the Bella Coola case study were designed to be replicable for analysis of other isolated communities in Canada and also remote/off-grid communities or industrial sites in other areas of the world. The project was generally divided into two biomass heating approaches: 1) a DES utilizing wood chips as the primary fuel for a centralized heat generation energy centre (which provides the possibility of electricity co-generation); and 2) a decentralized heating option with wood pellet boilers in each individual residence and commercial building. The potential for production of compressed particle fire logs or briquettes from mill and harvest residues was also initially considered since many homes already have wood stoves that could utilize the fire logs. However, given the abundance of cord wood in the community, the additional costs of fire log production relative to cord wood, and the lack of a significant convenience benefit compared to cord wood, an analysis was not completed. Fire log production or import to the community may be something worth considering as an 
incremental improvement but it would not result a fundamental, structural change to the heating system that is investigated in this research.

The study area was comprised of the village of Bella Coola including Nuxalk First Nation reserve land in Bella Coola, the reserve subdivision of Four Mile, and the township (non-reserve) lands of Bella Coola (Figure 1). Note that areas identified in the maps in this paper were for project purposes only and are used to determine which buildings will be included in each scenario. They are not intended to represent official boundaries between reserve and non-reserve lands or to identify traditional territories of the Nuxalk First Nation. The project was largely focused on the opportunities and benefits for the Nuxalk First Nation, but given the integrated electrical system connecting reserve and non-reserve buildings, and the potential to achieve economies-of-scale with a larger heating project, the non-reserve area of Bella Coola was included in some scenarios of the project.

The case study research required a survey of the community and this was carried out using a surveyor's wheel in June of 2013. The survey was used to determine approximate floor area of buildings and lengths of roads in Bella Cool and Four Mile. Given the large number of buildings, internal inspections were not completed. External dimensions and number of inhabited/active floors were identified and used to approximate heated floor area. The building dimensions from the survey were contrasted with those of a geographic information system (GIS) analysis. A notable difference between the two data approaches was expected given the inability to account for roof overhangs, unheated garages, porches, and unheated basements in the high-level GIS analysis. The ground survey results on building heated area were used for heat load analysis (precedence over GIS building area results), with the GIS analysis used for distance between buildings.

\subsection{District Energy System}

The DES component of the Nuxalk heating project included four different DES layouts, with the assumption that the centralized energy centre would be located in the western corner of Four Mile in close proximity to the local utility BC Hydro Ah-Sin-Heek diesel generating station (Figure 1). Potential energy centre sites include the forested area immediately to the east of the generating station (offreserve), the old sawmill site on the north side of Highway 20 (on-reserve), and across the road from AhSin-Heek (on-reserve). The selection of one site over another is not likely to affect the installation cost or performance of a DES significantly. The four DES scenarios assessed for this project were: 1 ) Four Mile - Roads: All the buildings in Four Mile are connected to the DES and all pipes are laid under existing roads; 2) Four Mile - Direct: Most buildings in Four Mile are connected to the DES and pipes are laid largely under existing roads, but some follow paths or cross through backyards in order to reduce cost; 3) Reserve Only: All buildings on reserve lands are connected to the DES, including those in Bella Coola village proper; 4) All Bella Coola and Four Mile: All buildings in Four Mile and Bella Coola are connected to the DES, including buildings on non-reserve lands.

A 0.5 m resolution orthophoto of Bella Coola and Four Mile, taken in 2006, was obtained from DataBC a repository of geographic data for the Province of British Columbia. It was imported into ArcMap 10.1 and georeferenced using the 'Streets' basemap provided by Esri, the designer of ArcMap GIS software. The georeferencing used five control points and the average residual was less than $4 \mathrm{~m}$. It was then transformed using the Canada Lambert Conformal Conic projection. This coordinate system was chosen because it retains distance integrity and allowed for accurate quantification of distances and areas in the study region. Shapefiles for roads and buildings, again using the Canada Lambert Conformal Conic projection, were created in ArcCatalog. Buildings and roads were then vectorized in ArcMap. These served as the basis for laying out the DES piping pathways, including connections to each building. The 
'calculate geometry' function in ArcMap was used to determine both the approximate building footprint, as dictated by roof area, and the length of roads and pipes to connection points on each building. The building footprint calculated using GIS was compared to the footprint determined in the ground survey, with the ground survey results taking precedence. Four DES scenarios were created and the required pipe diameter for each section of pipe, as dictated by combined peak heating loads of the serviced buildings, was determined. Peak heating load for each building was calculated by combining survey estimates on heated floor area with specific space peak heat load $\left(\mathrm{W} / \mathrm{m}^{2}\right)$ estimates from RetScreen. RetScreen is a spreadsheet-based clean energy project analysis software tool supplied by Natural Resources Canada, a department of the federal Government of Canada [8]. Given the large variety of building conditions (but generally medium to poor insulation) and age, and the $\mathrm{BC}$ coastal climate of Bella Coola, it was assumed that the average peak load for the community is $60 \mathrm{~W} / \mathrm{m}^{2}$. Data on pipe length and diameter was then used to determine the cost of installation of each pipe segment, with diameter-specific costing sourced from RetScreen and compared to previous installations. A $10 \%$ cost premium was assumed because of the remote location of the community.

\subsection{Decentralized Wood Pellet Boilers}

The decentralized heating component of the project examined the cost of installing and operating wood pellet boilers, ranging in scale from $10 \mathrm{~kW}$ to $150 \mathrm{~kW}$, at each building in Bella Coola and Four Mile. Given that the vast majority of buildings in Bella Coola (especially the Reserve portion) and Four Mile are residences and pellets are a much easier fuel for residential customers than wood chips, pellet boilers were selected for all buildings. In many cases, existing furnaces could be utilized to distribute heat produced by the boiler. Longer term, newly built residences and other buildings could include hydronic (water-based) systems, such as in-floor heating, for heat distribution. The largest pellet boiler considered for this analysis, $150 \mathrm{~kW}$, can also use wood chips if required. Cord wood (firewood) boilers were not selected for the analysis because many homes in Bella Coola already have wood stoves and switching to a cord wood boiler would not have a large operational benefit in buildings lacking hydronic heat distribution systems. However, their installation should be considered when existing wood stoves require replacing or major repair. It is important to note that cord wood boilers have approximately half the capital cost of wood pellet boilers and could be particularly useful for reducing hot water electricity consumption. The benefit of utilizing pellets as fuel is the ease of handling and automatic, continuous operation that is similar to heating oil or natural gas furnaces. Local boiler distributors provided quotations on the purchase and installation of the boilers, with scaling factors used to fill gaps in the non-confidential data. A $30 \%$ discount was applied to retail prices to estimate unit prices for a large volume, community-wide bulk purchase.

For the purposes of this heating analysis, it was assumed that wood pellets would be delivered by truck from Williams Lake. There is a 150,000 tonne per year pellet plant in Williams Lake that could potentially supply pellets in bulk - a much lower cost option than individual bags [9]. Heat demand estimates were based upon RetScreen data and the survey of homes [8]. 
Figure 1. Study Area of Bella Coola Village and Four Mile Subdivision

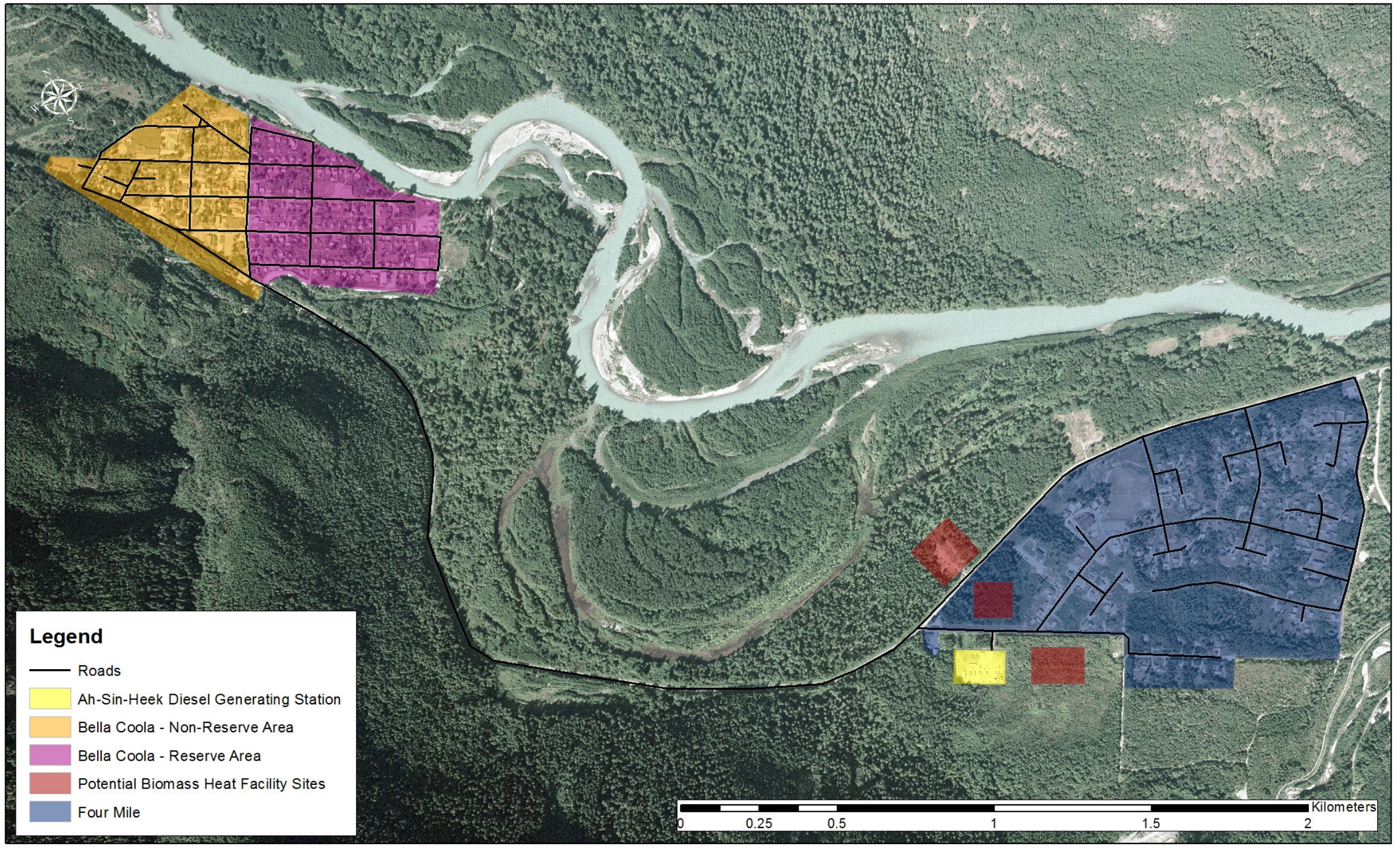




\section{Results}

\subsection{District Energy System}

Visual representations of the four DES scenarios are presented in Figures 2-5. The peak heat load, based upon an average specific peak load of $60 \mathrm{~W} / \mathrm{m}^{2}$, for each system is presented in Table 2. Pipe lengths of each system, which were identified using the 'calculate geometry' feature of ArcMap, are presented in Table 3. Pipe diameter (size) selections, identified in Table 3 (and Figures 2-5), were based upon the combined peak heat load of the connected buildings. Pipe diameter is dictated by the peak heat load, since $100 \%$ of heat requirements are assumed to be met by the DES. RetScreen data and modelling were used to identify the pipe diameter required for the heat loads [8]. Heat losses, which are minimal, were not incorporated into the pipe sizing, since the system will operate for most of the year at below peak load.

A scaling equation was used to determine the capital cost of pumps and the central energy centre. A scaling factor, which is a ratio of the change in scale relative to the change in cost, is a key component of the equation. The equation used to calculate cost at different scales is:

$$
\frac{C_{1}}{C_{0}}=\left(\frac{M_{1}}{M_{0}}\right)^{s}
$$

Where $M_{0}$ is the capacity of the base facility, $M_{1}$ is the capacity of the study facility, $C_{0}$ is the total installed cost of the base facility, $C_{1}$ is the total installed cost of the study facility, and $s$ is the scaling factor [10].

The costs of pipe installation, DES pumps, building connections, and the energy centres are presented in Tables 4 through 7. Pipe and pipe installation costs were sourced from RetScreen and compared to previous estimates (e.g., [11][12][13]). It should be noted that a geological survey of the area was not performed and the soil depth (and hence depth to bedrock/rocky drift) will impact the costs of excavation. However, the area is composed of rich alluvial soils (which support the growth of largediameter trees), drinking water supply pipes already run throughout the community, septic tanks are common, and the land in question is generally Class 3-5 agricultural land [14]. Therefore, it is not envisioned that rock blasting would be required. Required pump capacity was determined using data on water flow and total head (pressure), the former calculated by adding actual head (altitude distance) and friction losses. Pump costs were originally estimated using a scaling formula with a scaling factor of 0.6 for pumps between $20 \mathrm{hp}$ and $100 \mathrm{hp}$ and 0.5 for pumps greater than $100 \mathrm{hp}$. The base cost was $\$ 8,000$ for a $5 \mathrm{HP}$ pump [15]. However, when compared to quotes provided by pump suppliers, the pump suppliers' prices were significantly lower (50-65\% lower). These quotes were used for calculation of economic performance, although it should be noted that pump capital cost is a small contributor to total capital cost. Building connection costs, which will be highly variable depending upon building architecture and existing heating systems, were estimated based upon data from previous studies (e.g., [12][13]). Forced-air heating systems (e.g., heating oil, propane) could be retrofit to utilize heat from a district energy system by adding a hydronic heat exchanger to each home and then installing a small hydronic loop between the heat exchanger and the existing furnace air handler. Hydronic heating coils could be installed in the air handlers to heat the forced air (same principle as air conditioning). Energy centre capital costs were based upon quotes from suppliers and modified for each scenario using the scaling formula and a scaling factor of 0.5. This factor was based upon confidential quotes on smallscale biomass boilers received from engineering, procurement, construction (EPC) suppliers. The installation factor, the ratio of installed cost to the purchase cost of equipment, for both pumps and biomass boilers was sourced from the literature and discussed with equipment suppliers [16]. Total capital costs for the DES scenarios are presented in Table 8 and range from $\$ 7.9 \mathrm{M}$ for Scenario 2 - Four 
Mile Direct to $\$ 18.3 \mathrm{M}$ for Scenario 4 - All Bella Coola and Four Mile. Total capital costs are dominated by piping cost and biomass energy centre (combustor, boiler, and balance-of-plant) cost. 


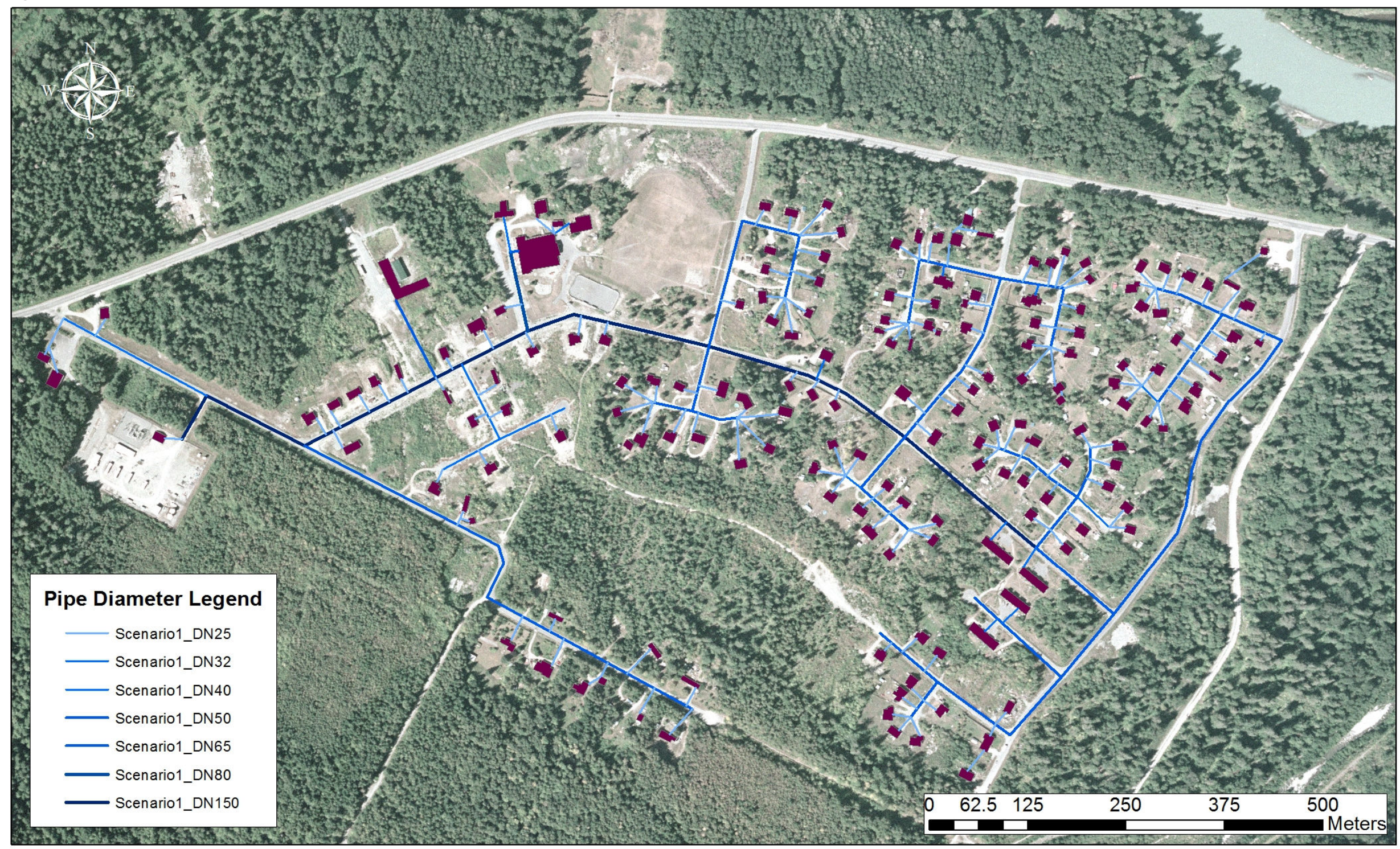




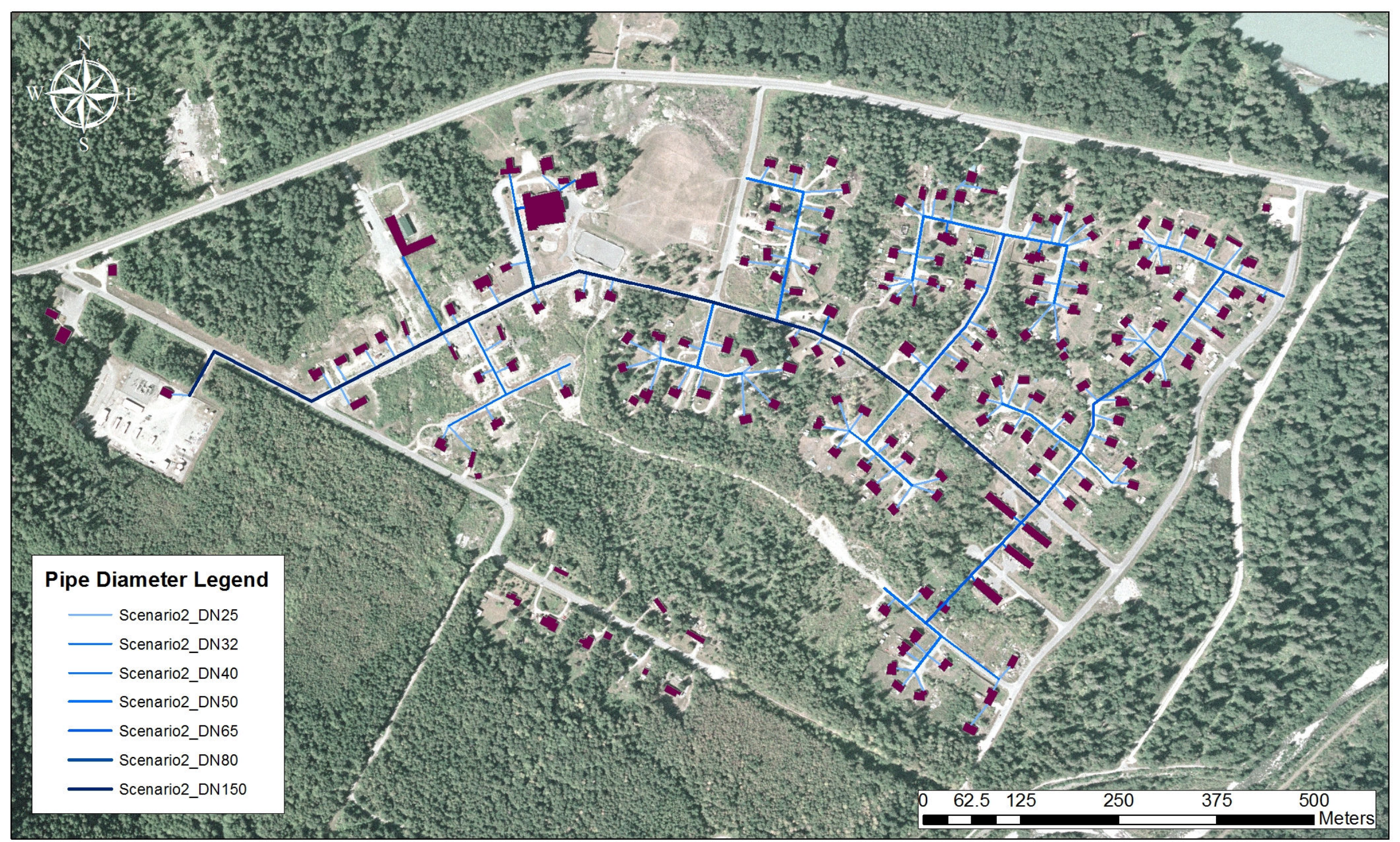




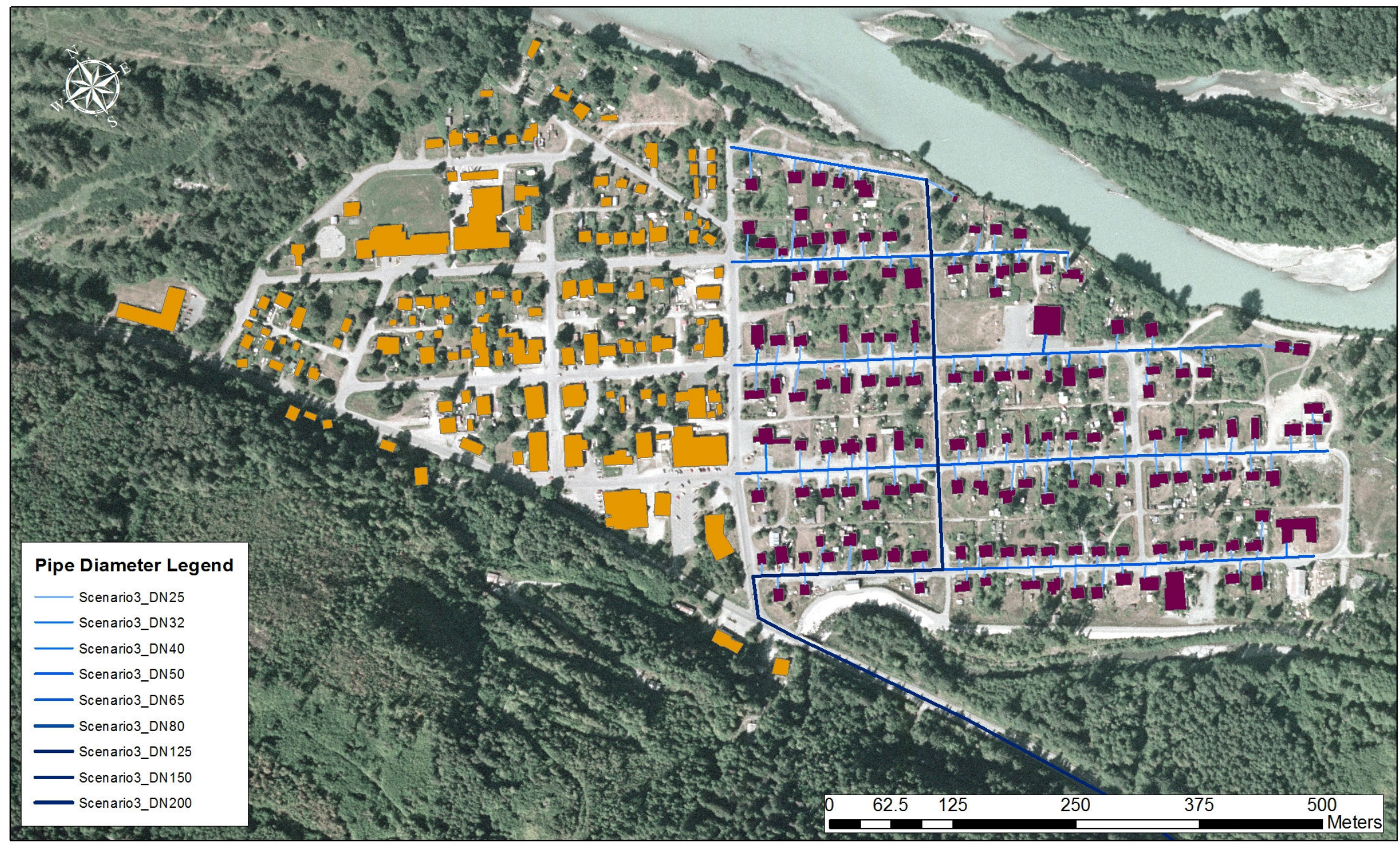




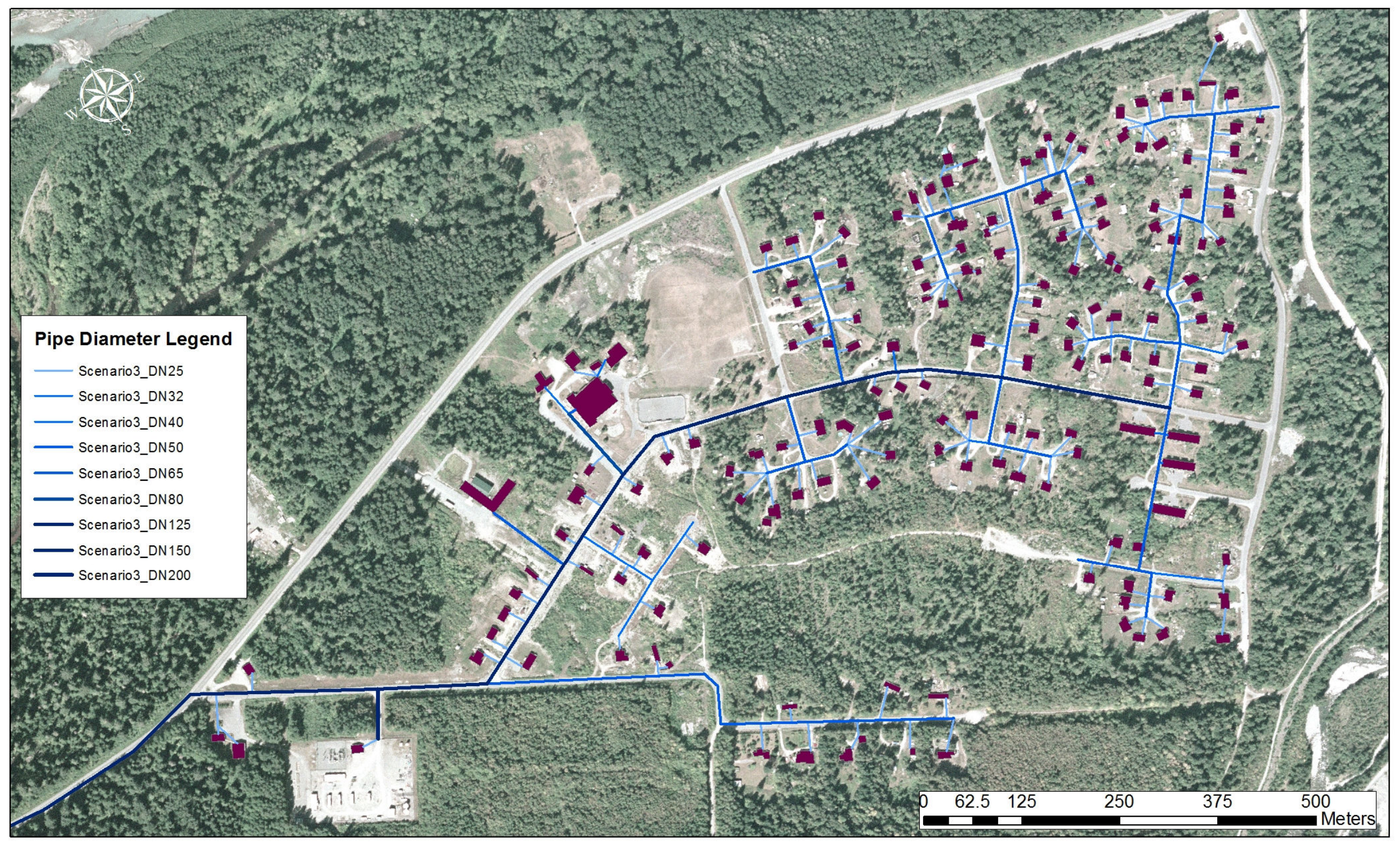




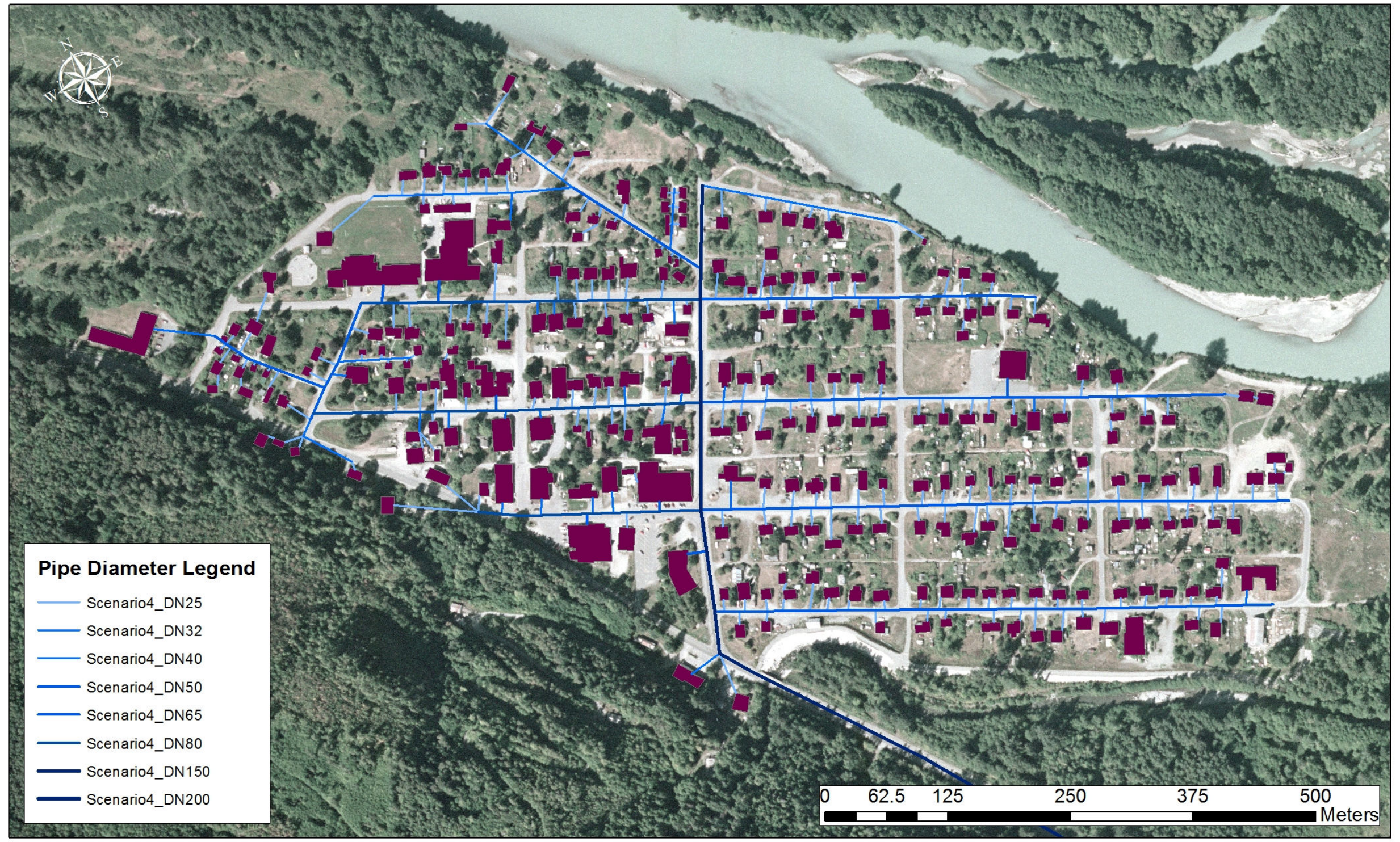




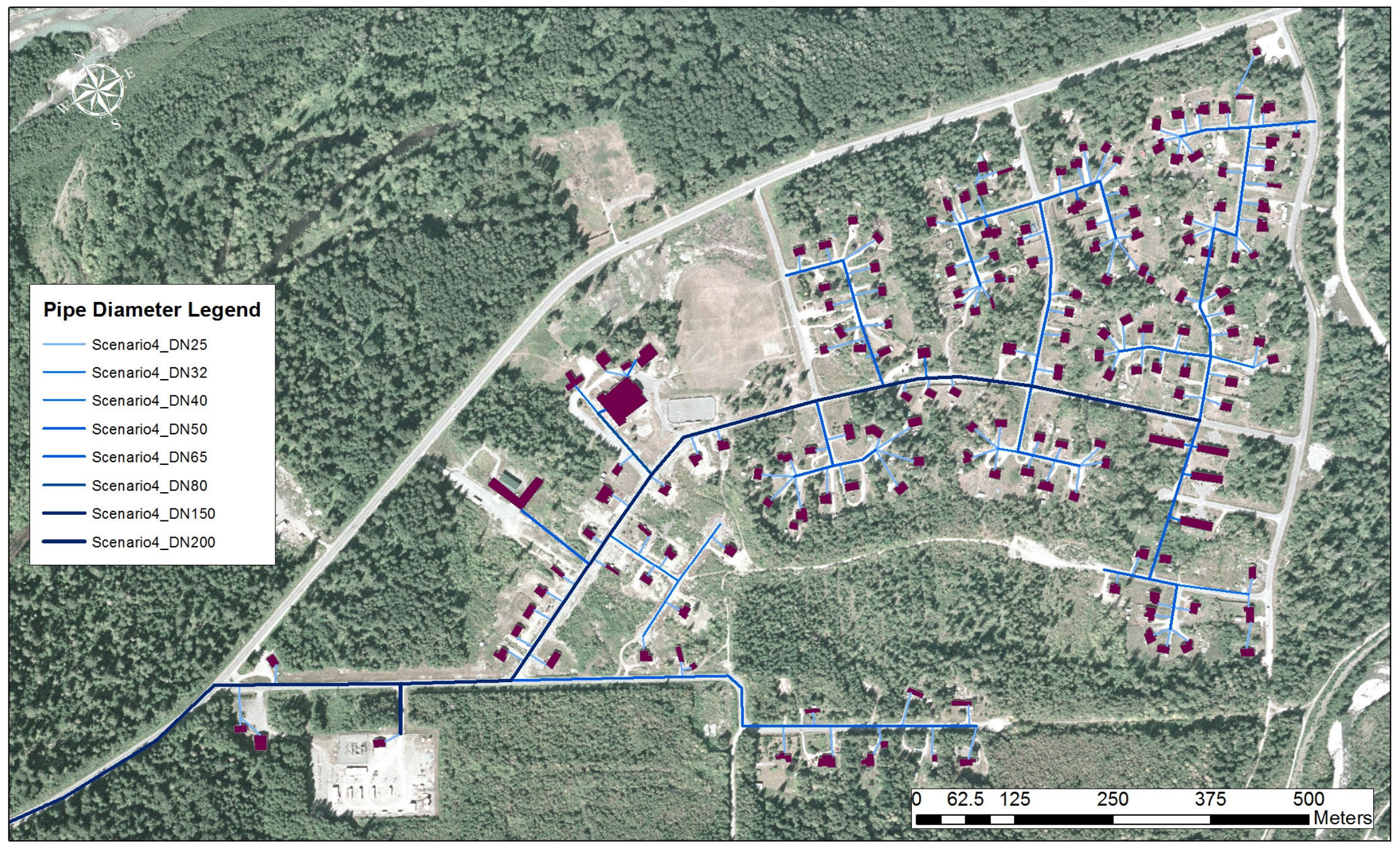


Table 2. Heating Load for DES Scenarios

\begin{tabular}{|c|c|c|c|c|c|}
\hline Scenario & $\begin{array}{l}\text { Connected } \\
\text { Buildings }\end{array}$ & $\begin{array}{l}\text { Heated Floor } \\
\text { Area }\left(\mathrm{ft}^{2}\right)\end{array}$ & $\begin{array}{l}\text { Heated Floor } \\
\text { Area }\left(\mathrm{m}^{2}\right)\end{array}$ & $\begin{array}{l}\text { Average Peak Heat } \\
\text { Load }\left(\mathrm{W} / \mathrm{m}^{2}\right)\end{array}$ & $\begin{array}{l}\text { Peak Heat } \\
\text { Load }(k W)\end{array}$ \\
\hline 1 - Four Mile Roads & 174 & 375,979 & 34,930 & 60 & 2,096 \\
\hline 2 - Four Mile Direct & 161 & 360,974 & 33,536 & 60 & 2,012 \\
\hline 3-Reserve Only & 315 & 586,244 & 54,464 & 60 & 3,268 \\
\hline $\begin{array}{l}\text { 4-All Bella Coola \& } \\
\text { Four Mile }\end{array}$ & 443 & 932,391 & 86,622 & 60 & 5,197 \\
\hline
\end{tabular}

Table 3. Pipe Length of Various Pipe Diameters for DES Scenarios

\begin{tabular}{|c|c|c|c|c|c|c|c|c|c|c|}
\hline \multirow{3}{*}{ Scenario } & \multicolumn{9}{|c|}{ Pipe Diameter Nominal (DN) in Millimeters } & \multirow{2}{*}{ Total } \\
\hline & DN25 & DN32 & DN40 & DN50 & DN65 & DN80 & DN125 & DN150 & DN200 & \\
\hline & \multicolumn{10}{|c|}{ Required Pipe Length (Meters) } \\
\hline $\begin{array}{l}1 \text { - Four Mile } \\
\text { Roads }\end{array}$ & 4,132 & 333 & 551 & 2,986 & 797 & 103 & 0 & 1,257 & 0 & 10,159 \\
\hline $\begin{array}{l}2-\text { Four Mile } \\
\text { Direct }\end{array}$ & 3,610 & 301 & 333 & 1,421 & 935 & 103 & 0 & 1,257 & 0 & 7,960 \\
\hline $\begin{array}{l}3-\text { Reserve } \\
\text { Only }\end{array}$ & 6,167 & 364 & 316 & 4,146 & 964 & 103 & 3,852 & 1,194 & 63 & 17,169 \\
\hline $\begin{array}{l}\text { 4-All Bella } \\
\text { Coola \& Four } \\
\text { Mile }\end{array}$ & 7,813 & 867 & 913 & 2,751 & 2,855 & 1,073 & 0 & 4,894 & 63 & 21,229 \\
\hline
\end{tabular}

Table 4. Assumed Installed Cost for Various Pipe Sizes

\begin{tabular}{|l|c|c|c|c|c|c|c|c|c|}
\hline $\begin{array}{l}\text { Pipe Diameter Nominal (DN) in } \\
\text { Millimeters }\end{array}$ & DN25 & DN32 & DN40 & DN50 & DN65 & DN80 & DN125 & DN150 & DN200 \\
\hline Installed Cost $\mathbf{( \$ / m ) ~}$ & 300 & 325 & 350 & 375 & 420 & 450 & 590 & 650 & 800 \\
\hline
\end{tabular}

Table 5. DES Scenario Pump Characteristics and Cost

\begin{tabular}{|l|c|c|c|c|c|c|c|c|c|c|}
\hline Scenario & $\begin{array}{c}\text { Actual } \\
\text { Feet of } \\
\text { Head }\end{array}$ & $\begin{array}{c}\text { mm } \\
\text { Water } \\
\text { Column }\end{array}$ & $\begin{array}{c}\text { Total } \\
\text { Feet } \\
\text { of } \\
\text { Head }\end{array}$ & $\begin{array}{c}\text { Flow } \\
\text { Rate } \\
\text { (GPM) }\end{array}$ & $\begin{array}{c}\text { Pump } \\
\mathbf{1}(\mathbf{H P})\end{array}$ & $\begin{array}{c}\text { Pump } \\
\mathbf{2}(\mathbf{H P})\end{array}$ & $\begin{array}{c}\text { Total Pump } \\
\text { Electrical } \\
\text { Load (kW) }\end{array}$ & $\begin{array}{c}\text { Capital } \\
\text { Cost }\end{array}$ & $\begin{array}{c}\text { Install } \\
\text { Factor }\end{array}$ & $\begin{array}{c}\text { Total } \\
\text { Pump } \\
\text { Cost }\end{array}$ \\
\hline $\begin{array}{l}\text { 1-Four } \\
\text { Mile } \\
\text { Roads }\end{array}$ & 90 & 171,535 & 561 & 400 & 65 & 50 & 86 & $\$ 19,000$ & 2.3 & $\$ 44,000$ \\
\hline $\begin{array}{l}\text { 2-Four } \\
\text { Mile } \\
\text { Direct }\end{array}$ & 90 & 130,876 & 430 & 400 & 55 & 40 & 71 & $\$ 17,000$ & 2.3 & $\$ 39,000$ \\
\hline $\begin{array}{l}3- \\
\text { Reserve } \\
\text { Only }\end{array}$ & 130 & 310,664 & 1020 & 700 & 190 & 150 & 254 & $\$ 46,000$ & 2.3 & $\$ 106,000$ \\
\hline $\begin{array}{l}4-\text { All } \\
\text { Bella } \\
\text { Coola \& } \\
\text { Four Mile }\end{array}$ & 140 & 381,470 & 1253 & 800 & 260 & 210 & 350 & $\$ 59,000$ & 2.3 & $\$ 136,000$ \\
\hline
\end{tabular}


Table 6. Cost of DES Connections

\begin{tabular}{|l|c|c|c|c|c|}
\hline \multicolumn{1}{|c|}{ Scenario } & $\begin{array}{c}\text { Residential } \\
\text { Connections }\end{array}$ & $\begin{array}{c}\text { Commercial } \\
\text { Connections }\end{array}$ & $\begin{array}{c}\text { Residential } \\
\text { Connection Cost } \\
\text { (Per Unit) }\end{array}$ & $\begin{array}{c}\text { Commercial } \\
\text { Connection Cost } \\
\text { (Per Unit) }\end{array}$ & $\begin{array}{c}\text { Total Connection } \\
\text { Cost }\end{array}$ \\
\hline 1-Four Mile Roads & 168 & 6 & $\$ 7,500$ & $\$ 15,000$ & $\$ 1,350,000$ \\
\hline 2-Four Mile Direct & 155 & 6 & $\$ 7,500$ & $\$ 15,000$ & $\$ 1,253,000$ \\
\hline 3-Reserve Only & 305 & 10 & $\$ 7,500$ & $\$ 15,000$ & $\$ 2,438,000$ \\
\hline $\begin{array}{l}\text { 4-All Bella Coola \& Four } \\
\text { Mile }\end{array}$ & 401 & 42 & $\$ 7,500$ & $\$ 15,000$ & $\$ 3,638,000$ \\
\hline
\end{tabular}

Table 7. Cost of Centralized Biomass Energy Centre for DES Scenarios

\begin{tabular}{|l|c|c|c|c|}
\hline \multicolumn{1}{|c|}{ Scenario } & Facility Scale (MW) & Equipment Cost (\$M) & Installation Factor & Installed Cost (\$M) \\
\hline 1- Four Mile Roads & 2.1 & 2.5 & 1.4 & 3.5 \\
\hline 2- Four Mile Direct & 2.0 & 2.4 & 1.4 & 3.4 \\
\hline 3- Reserve Only & 3.3 & 3.1 & 1.4 & 4.3 \\
\hline $\begin{array}{l}\text { 4- All Bella Coola \& } \\
\text { Four Mile }\end{array}$ & 5.2 & 3.9 & 1.4 & 5.5 \\
\hline
\end{tabular}

Table 8. Total DES Capital Cost

\begin{tabular}{|l|c|c|c|c|c|}
\hline \multicolumn{1}{|c|}{ Scenario } & Piping Cost & Pump Cost & $\begin{array}{c}\text { Connection } \\
\text { Cost }\end{array}$ & $\begin{array}{c}\text { Biomass Energy Centre } \\
\text { Cost }\end{array}$ & $\begin{array}{c}\text { Total System Capital } \\
\text { Cost }\end{array}$ \\
\hline 1- Four Mile Roads & $\$ 3,859,000$ & $\$ 44,000$ & $\$ 1,350,000$ & $\$ 3,500,000$ & $\$ 8,753,000$ \\
\hline 2- Four Mile Direct & $\$ 3,087,000$ & $\$ 39,000$ & $\$ 1,253,000$ & $\$ 3,400,000$ & $\$ 7,779,000$ \\
\hline 3- Reserve Only & $\$ 7,185,000$ & $\$ 106,000$ & $\$ 2,438,000$ & $\$ 4,300,000$ & $\$ 14,029,000$ \\
\hline $\begin{array}{l}\text { 4-All Bella Coola \& } \\
\text { Four Mile }\end{array}$ & $\$ 8,891,000$ & $\$ 136,000$ & $\$ 3,638,000$ & $\$ 5,500,000$ & $\$ 18,165,000$ \\
\hline
\end{tabular}

\subsection{Decentralized Wood Pellet Boilers}

The data on heated floor area from the community survey, combined with RetScreen data on climate, was used to determine peak heat load. This peak load was then used to identify the appropriate wood pellet boiler that would meet all heating requirements (both space and hot water) for each building in Bella Coola and Four Mile. The wood pellet boiler options were based upon product offerings available in the British Columbia market and ranged from $10 \mathrm{~kW}$ to $150 \mathrm{~kW}$. Only two buildings in Bella Coola, the hospital and the hotel, required more than one boiler. The school in Four Mile would have required multiple boilers, but due to the use of geothermal heat, a single $150 \mathrm{~kW}$ boiler was considered sufficient. The number of wood pellet boilers and boiler capacities required for Bella Coola and Four Mile is presented in Table 9.

Table 9. Wood Pellet Boilers and Capacity for Decentralized Heating

\begin{tabular}{|c|c|c|c|c|c|c|c|c|c|c|c|c|c|}
\hline \multirow{2}{*}{ Area } & \multicolumn{11}{|c|}{ Boiler Capacity (kW) } & \multirow{2}{*}{$\begin{array}{c}\text { Total } \\
\text { Boilers }\end{array}$} & \multirow{2}{*}{$\begin{array}{l}\text { Total kW } \\
\text { Capacity }\end{array}$} \\
\hline & 10 & 15 & 20 & 25 & 32 & 38 & 48 & 60 & 80 & 100 & 150 & & \\
\hline $\begin{array}{l}\text { Bella Coola } \\
\text { (Reserve) }\end{array}$ & 110 & 11 & 5 & 1 & 2 & 0 & 0 & 0 & 1 & 0 & 1 & 131 & 1738 \\
\hline $\begin{array}{l}\text { Bella Coola (Non- } \\
\text { Reserve) }\end{array}$ & 57 & 13 & 3 & 6 & 3 & 4 & 3 & 1 & 6 & 2 & 2 & 100 & 2433 \\
\hline Four Mile & 112 & 37 & 4 & 2 & 1 & 3 & 0 & 0 & 0 & 0 & 2 & 161 & 2303 \\
\hline Combined & 279 & 61 & 12 & 9 & 6 & 7 & 3 & 1 & 7 & 2 & 5 & 392 & 6474 \\
\hline
\end{tabular}


A Canadian distributor of European wood pellet boilers provided retail pricing for several pellet boiler capacities. The scaling equation was used to determine pricing of other units. After discussing the potential of a bulk purchase of boilers with boiler suppliers, a $30 \%$ volume discount was deemed to be a reasonable assumption. For all units, an installation factor - the ratio of installed capital cost relative to equipment purchase cost - was used to determine installed cost (including labour). Installation factors will typically vary by size of boiler (smaller boilers cost more to install relative to equipment cost) and building. Given the large number of variables and the need for a home-by-home inspection, a general installation factor of 1.4 was used for the analysis. Installed costs for various scenarios are presented in Table 10. 
Table 10. Capital Cost for Decentralized Bioheat in Bella Coola Proper (Reserve Only)

\begin{tabular}{|c|c|c|c|c|c|c|c|c|c|c|c|c|}
\hline & $10 \mathrm{KW}$ & $15 \mathrm{KW}$ & $20 \mathrm{KW}$ & $25 \mathrm{KW}$ & $32 \mathrm{KW}$ & $38 \mathrm{KW}$ & $48 \mathrm{KW}$ & $60 \mathrm{KW}$ & $80 \mathrm{KW}$ & $100 \mathrm{KW}$ & $150 \mathrm{KW}$ & TOTAL \\
\hline $\begin{array}{l}\text { Equipment } \\
\text { Cost }\end{array}$ & $\$ 13,670$ & $\$ 16,572$ & $\$ 19,484$ & $\$ 22,028$ & $\$ 25,232$ & $\$ 27,733$ & $\$ 31,535$ & $\$ 35,160$ & $\$ 41,765$ & $\$ 47,219$ & $\$ 90,000$ & - \\
\hline $\begin{array}{l}\text { Installation } \\
\text { Factor }\end{array}$ & 1.4 & 1.4 & 1.4 & 1.4 & 1.4 & 1.4 & 1.4 & 1.4 & 1.4 & 1.4 & 1.4 & - \\
\hline $\begin{array}{l}\text { Installed } \\
\text { Cost }\end{array}$ & $\$ 19,138$ & $\$ 23,200$ & $\$ 27,278$ & $\$ 30,840$ & $\$ 35,324$ & $\$ 38,826$ & $\$ 44,149$ & $\$ 49,224$ & $\$ 58,471$ & $\$ 66,106$ & $\$ 126,000$ & - \\
\hline \multicolumn{13}{|c|}{ BELLA COOLA PROPER (RESERVE ONLY) } \\
\hline Units & 110 & 11 & 5 & 1 & 2 & 0 & 0 & 0 & 1 & 0 & 1 & 131 \\
\hline Retail Cost & $\$ 2,105,180$ & $\$ 255,204$ & $\$ 136,389$ & $\$ 30,840$ & $\$ 70,649$ & - & - & - & $\$ 58,471$ & - & $\$ 126,000$ & $\$ 2,782,733$ \\
\hline $\begin{array}{l}\text { Discounted } \\
\text { Cost }\end{array}$ & $\$ 1,654,070$ & $\$ 200,517$ & $\$ 107,163$ & $\$ 24,231$ & $\$ 55,510$ & - & - & - & $\$ 45,942$ & - & $\$ 99,000$ & $\$ 2,186,433$ \\
\hline \multicolumn{13}{|c|}{ FOUR MILE } \\
\hline Units & 112 & 37 & 4 & 2 & 1 & 3 & 0 & 0 & 0 & 0 & 2 & 161 \\
\hline Retail Cost & $\$ 2,143,456$ & $\$ 858,414$ & $\$ 109,111$ & $\$ 61,679$ & $\$ 35,324$ & $\$ 116,478$ & - & - & - & - & $\$ 252,000$ & $\$ 3,576,463$ \\
\hline $\begin{array}{l}\text { Discounted } \\
\text { Cost }\end{array}$ & $\$ 1,684,144$ & $\$ 674,468$ & $\$ 85,730$ & $\$ 48,462$ & $\$ 27,755$ & $\$ 91,519$ & - & - & - & - & $\$ 198,000$ & $\$ 2,810,078$ \\
\hline \multicolumn{13}{|c|}{ ALL BELLA COOLA AND FOUR MILE } \\
\hline Retail Cost & $\$ 5,339,502$ & $\$ 1,415,222$ & $\$ 327,333$ & $\$ 277,557$ & $\$ 211,946$ & $\$ 271,782$ & $\$ 132,448$ & $\$ 49,224$ & $\$ 409,297$ & $\$ 132,212$ & $\$ 630,000$ & $\$ 9,196,527$ \\
\hline $\begin{array}{l}\text { Discounted } \\
\text { Cost }\end{array}$ & $\$ 4,195,323$ & $\$ 1,111,961$ & $\$ 257,190$ & $\$ 218,080$ & $\$ 166,529$ & $\$ 213,543$ & $\$ 104,067$ & $\$ 38,676$ & $\$ 321,594$ & $\$ 103,882$ & $\$ 495,000$ & $\$ 7,225,842$ \\
\hline
\end{tabular}




\subsection{Feedstock Demand}

Space and hot water heating systems do not operate at full load throughout the year due to climate variability (i.e., less heat is required in the summer for both space and hot water heating), even considering buffer tanks. RetScreen provides estimates of actual energy demand relative to peak demand based upon local climate conditions and these were used to estimate energy production and feedstock demand for both DES and decentralized heating options. Since climate data for Bella Coola are not included in RetScreen, Port Hardy Airport (the closest proximity site) climate data was utilized. However, it should be noted that Bella Coola has a somewhat drier and cooler winter than Port Hardy and a full climate-dictated energy demand analysis should be included as a component of a full feasibility study. The RetScreen data on Port Hardy Airport indicated that energy demand for space heating only is equivalent to approximately 2,975 full load hours per year (of a potential 8760 ). This is equal to $34 \%$ of full capacity at peak load. However, hot water increases the full load hours and energy demand. A traditional assumption is hot water demand is equal to $15 \%$ of space heating demand [8]. However, given the flat rate residents of Bella Coola pay for water, hot water demand was assumed to be equal to $20 \%$ of space heating demand. This increases the equivalent full load hours to 3690 and energy demand to $42 \%$ of full capacity at peak load. These numbers were used to estimate energy production and feedstock demand for the various DES scenarios and decentralized heating options. These are presented in Tables 11 and 12 along with assumptions on conversion efficiency and resulting feedstock demand. Energy content was calculated using an equation accounting for the latent energy required to evaporate water from biomass, which is dependent upon moisture content [17]. The energy content of bone dry wood chips and pellets was assumed to be 18.5 gigajoules (GJ) per bone dry tonne (bdt) and the moisture content of wood chips and pellets was assumed to be $40 \%$ and $7 \%$ respectively. It should be noted that many biomass DES' use propane or oil for meeting peak demand, which permits use of a smaller biomass energy centre. Due to the relatively flat load curve of Bella Coola, the benefits of such as design are less than in very cold climates. However, the role of propane and heating oil in a Bella Coola DES could be explored in a future full feasibility study.

Table 11. Feedstock Demand for DES Scenarios

\begin{tabular}{|l|c|c|c|c|c|c|}
\hline \multicolumn{1}{|c|}{ Scenario } & $\begin{array}{c}\text { Peak Load } \\
\text { (kW) }\end{array}$ & $\begin{array}{c}\text { Capacity } \\
\text { Factor }\end{array}$ & $\begin{array}{c}\text { Yearly Energy } \\
\text { Demand (MWh) }\end{array}$ & $\begin{array}{c}\text { Energy Content } \\
\text { (GJ/t) }\end{array}$ & $\begin{array}{c}\text { Conversion } \\
\text { Efficiency }\end{array}$ & $\begin{array}{c}\text { Feedstock } \\
\text { Demand (t/yr) }\end{array}$ \\
\hline 1- Four Mile Roads & 2,096 & $42 \%$ & 7,712 & 10.1 & $80 \%$ & 3,449 \\
\hline 2- Four Mile Direct & 2,012 & $42 \%$ & 7,403 & 10.1 & $80 \%$ & 3,311 \\
\hline 3- Reserve Only & 3,268 & $42 \%$ & 12,024 & 10.1 & $80 \%$ & 5,378 \\
\hline $\begin{array}{l}\text { 4-All Bella Coola \& } \\
\text { Four Mile }\end{array}$ & 5,197 & $42 \%$ & 19,121 & 10.1 & $80 \%$ & 8,553 \\
\hline
\end{tabular}

Table 12. Feedstock Demand for Decentralized Biomass Boiler Scenarios

\begin{tabular}{|l|c|c|c|c|c|c|}
\hline \multicolumn{1}{|c|}{ Scenario } & $\begin{array}{c}\text { Peak Load } \\
\mathbf{( k W )}\end{array}$ & $\begin{array}{c}\text { Capacity } \\
\text { Factor }\end{array}$ & $\begin{array}{c}\text { Yearly Energy } \\
\text { Demand (MWh) }\end{array}$ & $\begin{array}{c}\text { Energy Content } \\
\mathbf{( G J / t )}\end{array}$ & $\begin{array}{c}\text { Conversion } \\
\text { Efficiency }\end{array}$ & $\begin{array}{c}\text { Feedstock } \\
\text { Demand (t/yr) }\end{array}$ \\
\hline Bella Coola (Reserve) & 1,172 & $42 \%$ & 4,312 & 17.0 & $80 \%$ & 1,140 \\
\hline Four Mile* & 1,796 & $42 \%$ & 6,608 & 17.0 & $80 \%$ & 1,747 \\
\hline $\begin{array}{l}\text { All Bella Coola \& Four } \\
\text { Mile }\end{array}$ & 4,897 & $42 \%$ & 18,017 & 17.0 & $80 \%$ & 4,763 \\
\hline
\end{tabular}

*The difference in peak load for Four Mile between DES and Decentralized Options is due to inclusion of the full load of the Nuxalk School in the DES but only $1 / 3$ in the Decentralized 
Feedstock cost was assumed to be $\$ 95 /$ bdt $(\$ 57 / t)$ for chipped harvest residues and $\$ 207 /$ bdt $(\$ 193 / \mathrm{t})$ for pellets. It was assumed chipped harvest residues would be supplied by Nuxalk First Nation-owned Nuxalk Forestry Limited Partnership's forest operations in the South Bentinck Arm, chipped on site, trucked $10 \mathrm{~km}$ to a landing, barged $30 \mathrm{~km}$, and trucked $10 \mathrm{~km}$ to Four Mile. In order to save on loading and unloading costs, it was assumed that the fully loaded truck is barged between South Bentinck Arm and Bella Coola. Assumed costs were $\$ 30 /$ bdt for forwarding and chipping [18], $\$ 15 /$ bdt for trucking (see [19] for trucking model), and $\$ 50 /$ bdt for barging $(\$ 25 / \mathrm{bdt}$ in fuel, $\$ 15 / \mathrm{bdt}$ in other tug costs, and $\$ 10 /$ bdt in barge amortization and operating costs). Pellets were assumed to be purchased in bulk in Williams Lake for $\$ 130 / \mathrm{t}$ and trucked $450 \mathrm{~km}$ from Williams Lake to Bella Coola. This transportation cost was estimated to be $\$ 52 / \mathrm{bdt}(\$ 48 / \mathrm{t}$ ) using a truck transportation model that assumed a payload of $40 \mathrm{t}$, driver salary of $\$ 35 / \mathrm{hr}$, truck and trailer capital cost of $\$ 170,000$, diesel fuel cost of $\$ 1.30 / \mathrm{L}$, fuel consumption of $1.9 \mathrm{~km} / \mathrm{L}$, and repairs and maintenance of $\$ 0.60 / \mathrm{km}$ (see [19] for full discussion). Pellet storage and delivery in Bella Coola was assumed to be $\$ 15 / \mathrm{bdt}$.

\subsection{Cost of Heat Generation}

Yearly feedstock, capital, labour, other operating and maintenance costs, and the total cost of heat production are presented in Table 13. The DES was amortized over 25 years and the boilers from the decentralized option were amortized over 15 years. The cost of capital for both options was assumed to be $5 \%$. This compares with an available 25 year loan rate from the First Nations Finance Authority of $4.75 \%$ in September 2013 and $2.75 \%$ in July 2015 [20]. Non-feedstock, non-labour maintenance and operating costs were assumed to be $2 \%$ for both options. Pump electricity costs, at a rate of $\$ 0.13 / \mathrm{kWh}$, were added to the O\&M costs for DES scenarios. It was assumed that there is one full-time operator of the DES for 8 hours a day and an on-call operator for the remaining 16 hours per day. The full-time operator salary was set at $\$ 45 /$ hour and the on-call operator rate was assumed to be $\$ 5 /$ hour to be oncall. Labour costs for handling and delivery of pellets were included in the pellet price, so there is no separate labour cost for the decentralized options. It is worth noting that the $30 \%$ volume discount on boilers is not included in Figure 22. For a decentralized biomass boiler scenario encompassing all of Bella Cool and Four Mile, the annual cost would be $\$ 1.75 \mathrm{M}$ and the average cost of heat generation would be $\$ 97 / \mathrm{MWh}$.

Based upon the heating oil and propane consumption stated in Table 1 and the estimated energy consumption in Table 12, heating and propane currently account for approximately $37 \%$ of on-reserve heat consumption. Electricity is also used for heat - particularly for hot water heating - and it was estimated that approximately $50 \%$ of the electricity consumed in community is for the purposes of space and hot water heating. This is based upon BC Hydro electricity logs, differences between summer and winter consumption, and an assumption that hot water heat is equal to $20 \%$ of space heating. After accounting for the ground source heat pumps of the Nuxalk school and the band office (assumed to meet $80 \%$ of total heat demand for those buildings), which equal approximately $10 \%$ of total heat supply for on-reserve buildings, there is a 3,950 MWh difference between the expected demand of $12,000 \mathrm{MWh}$ and supply of $8,050 \mathrm{MWh}$. This difference, which is equal to one third of on-reserve heat supply, represents cord wood (and possibly some wood pellet) consumption in the community. In addition, since a general figure of $60 \mathrm{~W} / \mathrm{m}^{2}$ was assumed for all buildings and there is likely to be a lot of inter-building and inter-year variability, there is also a margin of error in heat demand figures. Assuming the full 3,950 MWh is met with cord wood, a cord of wood ( $2.5 \mathrm{~m}^{3}$ of solid wood) has an energy content of $21 \mathrm{GJ}$, and wood stoves have an efficiency of $75 \%$, this is equivalent to approximately 900 cords of wood [21]. Divided between approximately 275 residences, this is equal to 3.3 cords per residence. However, many older wood stoves have efficiencies of $35-40 \%$, which would double wood consumption to 6.6 cords per residence. In order to provide a conservative estimate of cost competitiveness of 
DES/boiler bioheat relative to wood stoves, the $75 \%$ wood stove efficiency was used. It should be noted that biomass DES and boilers are much more cost competitive with low efficiency wood stoves than high efficiency wood stoves due to the inverse relationship between efficiency and fuel costs for wood stoves.

Table 13. Yearly Costs and Cost of Heat for Biomass DES and Decentralized Options

\begin{tabular}{|c|c|c|c|c|c|c|c|}
\hline Scenario & $\begin{array}{l}\text { Peak Load } \\
\text { (kW) }\end{array}$ & Capital & Feedstock & Labour & O\&M & Total & $\begin{array}{l}\text { Average Cost of } \\
\text { Generation } \\
\text { (\$/MWh) }\end{array}$ \\
\hline \multicolumn{8}{|c|}{ Biomass District Energy System } \\
\hline $\begin{array}{l}1 \text { - Four Mile } \\
\text { Roads }\end{array}$ & 2,096 & $\$ 614,000$ & $\$ 197,000$ & $\$ 161,000$ & $\$ 216,000$ & $\$ 1,188,000$ & $\$ 154$ \\
\hline $\begin{array}{l}2 \text { - Four Mile } \\
\text { Direct }\end{array}$ & 2,012 & $\$ 546,000$ & $\$ 189,000$ & $\$ 161,000$ & $\$ 190,000$ & $\$ 1,086,000$ & $\$ 147$ \\
\hline $\begin{array}{l}\text { 3-Reserve } \\
\text { Only }\end{array}$ & 3,268 & $\$ 984,000$ & $\$ 307,000$ & $\$ 161,000$ & $\$ 402,000$ & $\$ 1,854,000$ & $\$ 154$ \\
\hline $\begin{array}{l}\text { 4-All Bella } \\
\text { Coola \& Four } \\
\text { Mile }\end{array}$ & 5,197 & $\$ 1,274,000$ & $\$ 488,000$ & $\$ 161,000$ & $\$ 531,000$ & $\$ 2,454,000$ & $\$ 128$ \\
\hline \multicolumn{8}{|c|}{ Decentralized Biomass Boilers } \\
\hline $\begin{array}{l}\text { Bella Coola } \\
\text { (Reserve) }\end{array}$ & 1,172 & $\$ 271,592$ & $\$ 220,056.91$ & - & $\$ 57,240$ & $\$ 549,000$ & $\$ 127$ \\
\hline Four Mile & 1,796 & $\$ 339,330$ & $\$ 337,220$ & - & $\$ 71,517$ & $\$ 748,000$ & $\$ 113$ \\
\hline $\begin{array}{l}\text { All Bella } \\
\text { Coola \& Four } \\
\text { Mile }\end{array}$ & 4,897 & $\$ 872,710$ & $\$ 919,470$ & & $\$ 183,931$ & $\$ 1,976,000$ & $\$ 110$ \\
\hline
\end{tabular}

Table 14. Business-as-Usual Heat Costs

\begin{tabular}{|c|c|c|c|c|c|}
\hline $\begin{array}{l}\text { Energy } \\
\text { Source }\end{array}$ & $\begin{array}{c}\text { Yearly } \\
\text { Consumption } \\
\text { (MWh) }\end{array}$ & $\begin{array}{l}\text { Proportion of } \\
\text { Supply }\end{array}$ & $\begin{array}{c}\text { Average Cost of } \\
\text { Generation } \\
\text { (\$/MWh) }\end{array}$ & $\begin{array}{c}\text { Total } \\
\text { Contribution }\end{array}$ & $\begin{array}{c}\text { Proportion of } \\
\text { Cost }\end{array}$ \\
\hline Heating Oil & 3,750 & $31 \%$ & $\$ 163$ & $\$ 611,000$ & $51 \%$ \\
\hline Propane & 700 & $6 \%$ & $\$ 141$ & $\$ 99,000$ & $8 \%$ \\
\hline Electricity & 2,400 & $20 \%$ & $\$ 130(\$ 410)$ & $\$ 312,000$ & $26 \%$ \\
\hline $\begin{array}{l}\text { Ground } \\
\text { Source }\end{array}$ & 1,200 & $10 \%$ & $-*$ & $\$ 0$ & - \\
\hline Cord wood & 3,950 & $33 \%$ & $\$ 46 * *$ & $\$ 182,000$ & $15 \%$ \\
\hline Total & 12,000 & $100 \%$ & $\$ 100(\$ 156)$ & $\$ 1,204,000$ & $100 \%$ \\
\hline
\end{tabular}

*Capital cost, amortization, and depreciation not included since costs are already sunk

$* *$ Reducing efficiency to $37.5 \%$, which is common with older stoves, would increase the cost of generation from cord wood to $\$ 92 / \mathrm{MWh}$ and average cost of generation to $\$ 115 / \mathrm{MWh}(\$ 171 / \mathrm{MWh})$

\section{Discussion}

The current average cost of heat for on-reserve residents is $\$ 100 / \mathrm{MWh}$, which is lower than all of the DES scenarios and the decentralized biomass boiler scenarios that exclude volume discounts. The primary reason the current average heating cost in Bella Coola is lower than all DES scenarios is the extensive use of low-cost cord wood and the assumption of $75 \%$ efficiency for wood stoves. A reduction in wood stove efficiency by $50 \%$ makes decentralized biomass boilers highly competitive with BAU. However, heating oil and propane, which are subject to substantial price swings over time, provide almost $40 \%$ of the heat for on-reserve buildings. The purchase and consumption of these fuels presents 
a significant risk for long-term heat costs, transfers wealth outside the community, and results in a high greenhouse gas (GHG) intensity for residents. The cost of heat from these fuels is also notably higher than the DES scenario 4 and all the decentralized biomass boiler scenarios. Therefore, any efforts to change the heating supply in Bella Coola should target these fuels. In addition, it is estimated that $20 \%$ of heat (with an emphasis on hot water) is from electricity. Since the cost of electricity is heavily subsidized in Bella Coola, the consumer cost of heating with electricity is similar to heating oil and propane. However, the real (generation) cost (vs. price) of heating with electricity is over $300 \%$ higher when produced from diesel-generated electricity. Diesel-fired electricity generation is also a major contributor to the community's GHG emissions.

All of the DES and decentralized biomass boiler scenarios presented here are uncompetitive with cord wood at wood stove efficiency of $75 \%$. Competitiveness is much greater when low efficiency (35-40\%) woods stoves are assumed. However, there is also clearly a demand for more convenient fuels, as evidenced by the consumption of heating oil and propane. Given the cost differential between cord wood and heating oil or propane, there would be much less fossil fuel consumption if cost were the only consideration. In addition, without a retrofit thermal coil, wood stoves are not typically designed to provide hot water to homes. In this case, residents resort to the use of electric water heaters. Therefore, pellet boilers may be an attractive option for some buildings on the reserve that utilize a large quantity of heating oil, propane, and/or electricity for heating. Each residence and building will vary, since the proportion of heat supplied by cord wood is a function of the whether the building has a stove, the amount of time in each day the residence is occupied, the design and size of the home, and the willingness of residents/owners to store, carry, and manage cord wood supplies.

The challenge of implementing a DES in Bella Coola is that it would displace not only high cost heating oil, propane, and electricity, but also low cost cord wood. The selection of decentralized wood pellet, or even cord wood, boilers allows a more targeted approach in changing the energy mix in the community. The volume-discounted decentralized wood pellet boiler scenarios are actually marginally lower cost than business-as-usual, which means they could be implemented without subsidies or support programs and still be economically viable. However, it is also important to note that because BC Hydro is selling electricity for less than $1 / 3$ the cost of diesel generation, the utility is incurring a major loss each year over $\$ 500,000$ per year for on-reserve electricity. This assumes diesel generation is $41 \%$ of the mix and has an estimated cost of generation of $\$ 0.41 / \mathrm{kWh}$. If $50 \%$ of this loss is due to hot water heating, the yearly loss for BC Hydro from on-reserve electric hot water heaters is $\$ 250,000$. If BC Hydro supported a wood pellet or cord wood boiler cost sharing program that covered $50 \%$ of the cost of a new boiler and install, they would recover all costs of the program within 5 (cord wood) to 10 (wood pellets) years.

Based upon the analyses presented here, it appears that a DES sourcing heat from a heat-only energy centre is not the lowest cost heating option for Bella Coola. This is largely due to the high capital cost of DES installation, relatively low housing density, and the extensive use of low cost firewood in the current heating fuel mix. However, this case study biomass heating research project has a sister project focused on combined heat and power (CHP) from biomass [22]. The CHP project examined the feasibility of implementing a CHP facility in Bella Coola to reduce diesel consumption in electricity generation and provide heat to a kiln for wood drying. Preliminary economic analyses show that when bioelectricity, which displaces diesel-fired electricity, is co-produced with heat, the much higher revenues can make a biomass CHP providing heat to a DES economically competitive. In addition, Bella Coola currently lacks a sewage system and the development of a DES could be significantly aided by the planning and installation of a sewage system at the same time. The trenching required for the sewage system could be used for the DES, thereby reducing capital costs substantially. Additional benefits of a centralized 
energy centre and associated DES compared to distributed boilers are the ability to consume wood chip fuel, which could provide a valuable source of revenue for the existing Nuxalk-owned sawmill through the sale of sawmill residues to the energy centre, and the lower air pollutant (e.g., particulates) of a central energy centre compared to hundreds of individual boilers and/or wood stoves.

\section{Conclusions}

These analyses and results indicate there could be several attractive biomass options to reduce heating costs in Bella Coola. Choices will need to be made about which path to pursue; a more centralized, utility approach with a biomass energy centre facility providing heat to a DES or a decentralized boiler approach. This research shows that a heat-only DES is not the lowest cost heating option and additional value will need to be derived from the biomass - likely in the form of electricity. The preferred option of CHP or decentralized boilers will be dictated partially by economics, but also by desire of the Nuxalk people to fundamentally change their energy infrastructure. The purchase and consumption of heating oil, propane, and diesel (as represented by electricity consumption) results in a transfer of wealth from inside to outside the remote community, while utilization of local biomass fuel (namely cord wood and/or wood chips) keeps wealth within the community. In addition, displacement of both diesel-fired electricity and propane/heating oil for heat would dramatically reduce the community's fossil fuel imports and GHG emissions - more so than displacement of fossil fuel-sourced heat alone. A DES would provide heat for space heating and hot water with almost zero effort on the part of residents. This could allow Nuxalk people to focus their time on other activities. A decentralized approach would require homeowners/residents to continue with their active management of fuel supply but has a cost advantage over a heat-only DES.

Due to the high capital cost, it is recommended that a DES be considered only if an additional higher value product beyond heat (likely electricity) is being co-generated by the biomass energy centre. This would provide additional revenues that could reduce the delivered cost of heat. On the other hand, the decentralized wood pellet boiler options were more competitive with business-as-usual and installation could target displacement of heating oil, propane, and electricity instead of cord wood for wood stoves. One particularly attractive option is the use of distributed biomass boilers to eliminate or reduce the use of electricity for hot water heating in Bella Coola. Since BC Hydro's cost of electricity generation from diesel fuel is estimated to be in excess of $\$ 0.40 / \mathrm{kWh}$ (and hence $>\$ 400 / \mathrm{MWh}$ for heat) but only charges residents $\$ 0.13 / \mathrm{kWh}$, the utility should have an incentive to encourage a reduction in the consumption of electricity used for hot water heating. The selection of wood pellet boilers vs. cord wood boilers to enable this reduction is likely to be made on a case-by-case basis. Establishment of a community pellet distribution system could help accelerate a shift to bioheat from heating oil and propane. It may be possible to produce a moderate volume of pellets in Bella Coola and improve Nuxalk Nation energy security.

Since Bella Coola has a relatively high population density compared to many remote, off-grid communities, it can be concluded that distributed biomass boilers in each building are likely to be more economically feasible than a heat-only DES for most remote communities. DES feasibility analyses for remote communities should always include co-generation of electricity at the central energy centre. Should a remote community have access to low-cost electricity (e.g., hydropower), it is unlikely that a DES will be economically competitive and a feasibility analysis justified. Unlike DES systems, which often utilize wood chips as fuel for a central energy centre, distributed boilers are more likely to operate on firewood or pellets. In most cases, firewood will be the lowest cost fuel for distributed heat generation in isolated communities with access to forest resources. Wood pellets are unlikely to be cost 
competitive with firewood (exclusive of opportunity cost and convenience benefits), but can compete with imported heating oil and propane. Regardless of the biomass fuel type, reducing electricity consumption in remote communities dependent upon diesel-fired electricity generation by installing distributed biomass boilers to displace electric hot water tanks will have significant economic benefits. This opportunity to reduce diesel consumption is present in the majority Canada's remote communities and a nation-wide effort to install biomass boilers in remote communities could have a notable impact on diesel consumption.

\section{Acknowledgements}

This research was completed within the Nuxalk Traditional Territory. The authors would like to acknowledge and thank the Nuxalk Hereditary Chiefs, Nuxalk elected Chief \& Council, Nuxalk elders and the Nuxalkmc people for their kind support, ideas and contributions toward this project. The Nuxalk Development Corporation (NDC), Mitacs, the Coast Opportunity Funds, and BioFuelNet Canada provided financial support for this research. The authors also thank BC Hydro for its willingness to provide data and to discuss the potential for bioenergy projects in the Bella Coola Valley microgrid. Natural Resources Canada is also acknowledged for supplying its RetScreen clean energy project analysis software, which was used in this project.

\section{References}

[1] Natural Resources Canada. North American natural gas market: 2013-2014 heating season outlook. 2013. http://www.nrcan.gc.ca/energy/natural-gas/12432 [Accessed 2014-06-12]

[2] Statistics Canada. Households and the environment: energy use. 11-526-S; 2007.

[3] Peksa-Blanchard M, Dolzan P, Grassi A, Heinimö J, Junginger M, Ranta T, Walter A. Global wood pellets markets and industry: policy drivers, market status and raw material potential. IEA Bioenergy Task 40; 2007.

[4] Shaw S. District energy in Canada. News from Danish Board of District Heating; 2002.

[5] McCallum B. Warming the neighbourhood. Canadian Biomass Magazine March-April; 2010.

[6] Pinna Sustainability. Nuxalk community energy plan. Phase 1: Energy inventory and opportunity assessment. Revised Draft; 2013.

[7] Statistics Canada. Community profiles - Bella Coola 1. Statistics Canada Catalogue no. 93F0053XIE; 2005.

[8] Natural Resources Canada. RetScreen. 2013.

[9] Canadian Biomass Magazine. Pellet map. 2012. http://www.pellet.org/images/CBM_Pelletmap2012FINAL.pdf [Accessed 2014-06-12]

[10] Jenkins BM. A comment on the optimal sizing of a biomass utilization facility under constant and variable cost scaling. Biomass Bioenerg 1997; 13:1-9.

[11] Hurtig J. Report-evaluation of a small scale district heating system in Ullared, Sweden. University of Halmstad; 2010.

[12] Pöyry Energy (Oxford) Ltd., Faber Maunsell AECOM. The potential and costs of district heating networks. A report for the UK Department of Energy and Climate Change; 2009.

[13] Arctic Energy Alliance. NWT community wood pellet district heating study. Prepared for the Government of the Northwest Territories Environment and Natural Resources; 2010. 
[14] Bella Coola Valley Sustainable Agricultural Society. Bella Coola Valley foodshed analysis project. 2008.

[15] Environmental Protection Agency. Public health and environmental radiation protection standards for Yucca Mountain, Nevada. Appendix IV - Well drilling and pumping costs. 2001.

[16] Humbird D, Davis R, Tao L, Kinchin C, Hsu D, Aden A, Schoen P, Lukas J, Olthof B, Worley M, Sexton $D$, Dudgeon D. Process design and economics for biochemical conversion of lignocellulosic biomass to ethanol. National Renewable Energy Laboratory, Golden, CO. NREL/TP-5100-47764; 2011.

[17] Stephen JD. The viability of lignocellulosic ethanol production as a business endeavour in Canada. PhD Thesis. The University of British Columbia; 2013.

[18] Macdonald AJ. Estimated costs for harvesting, comminuting, and transporting beetle-killed pine in the Quesnel/Nazko area of central British Columbia. Forest Engineering Research Institute of Canada; 2006.

[19] Stephen JD, Mabee WE, Saddler JN. Lignocellulosic ethanol production from woody biomass: The impact of facility siting on competitiveness. Energ Policy 2013; 59:329-340.

[20] First Nations Finance Authority. Amortization sheet. 2013. http://www.fnfa.ca/en/calculators/amortization-sheet/ [Accessed 2013-11-01]

[21] United States Environmental Protection Agency. Consumers - energy efficiency and wood-burning stoves and fireplaces. 2013. http://www.epa.gov/burnwise/energyefficiency.html [Accessed 201406-20]

[22] Pribowo A, Stephen JD. Biomass combined heat and power (CHP) options for the Nuxalk Nation. University of British Columbia. Prepared for the Nuxalk Development Corporation (Confidential). 2013. 